that moment by Horrocks, Simon During, Leigh Davis, Alex Calder, Wystan Curnow and others. Like most of that initial wave of poststructuralist work, Pound's analysis deconstructs more willingly than it historicizes. It's a critique, then, of rhetoric and representations, which seldom engages deeply with their historical contexts. And though it analyzes with great panache the ways in which painting is mediated by painting itself, it has relatively little to say about painting's mediation by gender and sexuality, and by anxieties of conquest. A 'big' book in many respects, its historicism is not quite as 'thick' as it might at first appear, and while it stands a summation of a lot of recent, sceptical work, it by no means addresses all the key problems that have occupied critics of the mid-century over the last couple of decades.

That said, however, The Invention of New Zealand is a terrific achievement. Beautifully produced by Auckland University Press - a fat, sturdy hardback with no less than 190 colour reproductions - it's a book entirely worthy of its long gestation, and which is sure to enjoy a long, busy shelf-life to match.

\title{
Whare Karakia: Māori Church Building, Decoration and Ritual in Aotearoa New Zealand 1834-1863
}

by Richard Sundt. Auckland University Press, Auckland, 2010 xiii, 225 pp. ISBN 9781869404567

Reviewed by Robin Skinner

When Richard Sundt arrived from Oregon in 1997 to lecture on Oceanic Art at Victoria University of Wellington, he had no idea that the outcome of this study leave would be an impressive body of research culminating in Whare Karakia: Māori Church Building, Decoration and Ritual in Aotearoa New Zealand 1834-1863. In Wellington he became aware of the Ōtaki church, Rangiātea (built 1848-51), which had been destroyed by arson two years earlier. This was one of a series of large wooden churches, or whare karakia, built by Māori between 1840-1863 that used a central row of prominent columns for structural support, and which were a supposed amalgam of two disparate traditions: neo-gothic church building and Māori whare structures. This book details the complex circumstances under which this series of large whare karakia developed, discusses the unique circumstances of their creation, considers how they operated liturgically and assesses the varied reasons for their success.

While a great deal of research on nineteenth-century church building in New Zealand has been undertaken, to date no single study has focused upon these churches as a coherent phenomenon. Sundt usefully extends a fragmented body of research on missionary church building to explore the conditions that gave rise to these whare karakia. After initially examining 
the then-prevalent Georgian tradition of the missionary churches of the 1820 s and 30s, Sundt considers how exposure to this European design and construction practice would have impacted upon Māori. His research of Māori architectural tradition includes archaeological evidence, early contact accounts of whare structures and a brief but significant acknowledgement of the role of the tohunga waihanga - the expert builder who determined design decisions.

Sundt rigorously assesses accounts of the early churches, reading various reports, testing them against visual records and making reasoned assessments of reliability. Floor areas and capacities are calculated, checked and compared. For many readers much of this information on the churches will be new; and when read in its entirety it provides fresh insight into the momentum of the missionary project far beyond the large churches with the central posts. Transfer of technology across cultures is also examined; for example, the little-known sketch by Rev. Richard Taylor [see opposite page] of a whare-style chapel at Whakawirita (a precursor to the large whare karakia) provides evidence of Māori working with two design traditions. While the chapel is built in traditional materials with central posts for support, it has a Georgian hipped roof formed with trusses made of timber squared with adzes and fastened with mortised and wooden nails. Sundt plausibly argues that the designer(s) took this roof design from the missionaries' chapels that they had seen near the Bay of Islands in the preceding decade. He does not draw attention to how the chapel floor was dug into the earth in the manner of some early whare. When considered as a vertical juxtaposition of the two architectural traditions, the interior then can be seen to be an intensely charged hybrid space. Other examples melding the traditions are recounted, including two Māori chapels along the Whanganui River which were constructed from pisé. Collectively, these developments present a hitherto unacknowledged swift, far reaching trail of influence and progression.

Seven large whare karakia with the central row of prominent columns figure large in this sequence and are discussed in detail in the middle section of the book. Much varied information is presented documenting the construction, materials and personnel involved. Period accounts highlight each achievement, and Sundt's methodical descriptions of each successive design give the reader a sense of how knowledge and aspiration compounded in a dynamic sequence. He even-handedly weights up various, often-partial historical accounts in order to determine an accurate, less-speculative record. For example, he assesses the likely construction method of the churches Manutūkē I (1840-42) and Rangiātea to soundly argue for the use of a block and tackle to raise the tâhuhu (ridge-beam) onto the tall supporting poutokomanawa (posts). Māori would have known of this technology and 


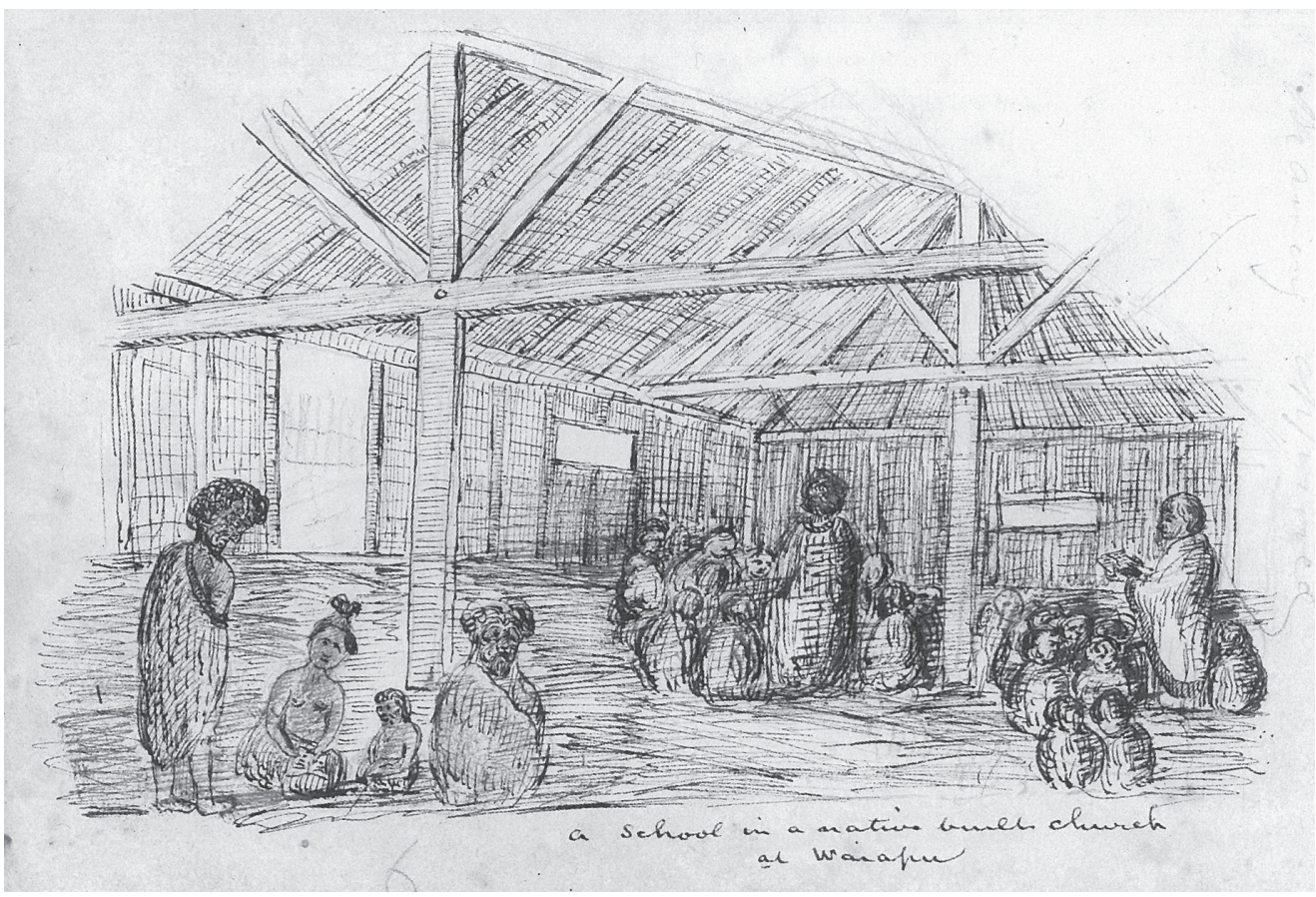

Richard Taylor, 'A school in a native built church at Waiapu' [Whakawiritā], Sketchbook Ms302, p.109, Auckland War Memorial Museum, c. 5578. Reproduced with permission.

would have used it in other endeavours. Recent archaeological investigation of the remains of Rangiātea reveals that the fixity between the poupou (wall posts) and heke (rafters) was another hybrid development incorporating diminished use of traditional flax fastening supplemented with six-inch square nails. At times Sundt's detailed commentary invites speculation. For example, one wonders if Māori designers had occasional access to illustrated magazines and books, and what impact visits to Sydney had upon Māori, who would have returned remembering the grandeur of Francis Greenway's brick Georgian St James' Church (1819-24).

While Sundt notes that sometimes Pākehā worked on these large projects, he usually assigns authority for design decisions to an unnamed tohunga waihanga (Waikanae p.104; Matamata p.105; Rangiātea pp.114, 119; Manutūkē IIB p.125). Without firm evidence, one wonders if this was always the case. The case of Manutūkē IIB is interesting in this respect as several tohunga whaikairo (master carvers) are named and others who adzed the timbers are also acknowledged. Hōhepa Tāepa records that discussion on the length of the tāhuhu of Rangiâtea lasted a day. Is it then possible that 
design decisions may not have always rested with one person, and instead may have developed through processes of debate and negotiation?

Throughout this study, the breadth and depth of Sundt's work impresses; however, his most astonishing single piece of research is his reconstituted interior of the large church, Manutūkē IIB (1849-63). The church has been largely known through a Church Missionary Society engraving produced before construction, which showed a large gathering of men in a whare karakia with five carved central posts and decorated with a series of prominent carved poupou at the gable end. As Sundt notes, there were two schemes for this church. In the first scheme (IIA) a series of the figurative carvings were rejected to be replaced by a scheme with less obviously human manaia figures (IIB). These manaia carvings were later incorporated into another church on the site which was subsequently destroyed by fire. Sundt has identified remnants of the figurative carvings from scheme IIA and found surviving examples of the manaia carvings and heke from scheme IIB. Comparing these remnants with historic photographs of the interior of the later church has enabled Sundt to determine the scheme for the manaia panels. While acknowledging the uncertainty that surrounds interpretation of manaia figures generally, Sundt tentatively suggests that these examples may have been an attempt to incorporate representations of human figures into the church without the awareness of the resident priest, the Rev. William Williams. This investigation is further discussed in two lengthy papers that Sundt published in the Journal of Polynesian Studies in 2008.

Sundt applies his reasoned approach to explain why the whare-style churches were adopted: they were very economical when compared with more elaborate English-style churches; technology and materials were available; they built upon and extended existing knowledge; execution was within the range of ability of both Māori and clergy; they were the vigorous creations of often competitive communities; and, they could entice ministers to communities. Without firm evidence, he is sceptical of the argument that the large whare-style churches were seen as a cultural device to attract Māori to the Pākehā faith. Later parts of the book dealing with the liturgical problems of the central pillars (which draw upon Sundt's earlier research on gothic double nave churches in Europe) and the discussion of seating patterns within the respective large whare karakia tend to divert from the central thesis of the book.

Nevertheless, this is a very rewarding piece of thorough, well-reasoned scholarship that will interest a diverse range of readers. It makes a major contribution for the material that it documents, and for the future research it will provoke. Sundt has convincingly identified how Māori 'readapted and reshaped' imported concepts to fit their indigenous context. Acknowledging other writers' statements on the impact of church building on the development 
of the meeting house in the nineteenth century, he suggests that the momentum that gave rise to the whare karakia became redirected towards the development of the whare rūnanga in subsequent decades. This, he proffers, demands further detailed work, which - along with many other issues that this study prompts - is an exciting prospect. 